\section{Tensile and Flexural Strength of CommerciallyPureTitanium Submitted to Laser and Tungsten Inert Gas Welds}

\author{
Juliana Abdallah Atoui ${ }^{1}$, Daniela Nair Borges Felipucci ${ }^{1}$, Valéria Oliveira \\ Pagnano ${ }^{1}$, lara Augusta Orsi ${ }^{1}$, Mauro Antônio de Arruda Nóbilo², Osvaldo \\ Luiz Bezzon ${ }^{1}$
}

'Department of Dental Materials and Prosthodontics, Ribeirão Preto School of Dentistry, USP - University of São Paulo, Ribeirão Preto, SP, Brazil ${ }^{2}$ Department of Prosthodontics and Periodontics, Piracicaba School of Dentistry, UNICAMP - University of Campinas, Piracicaba, SP, Brazil

Correspondence: Profa. Dra. Valéria Oliveira Pagnano, Avenida do Café s/n, 14040-904, Ribeirao Preto, SP, Brasil. Tel:+55-16-3604795, e-mail: valpag@forp.usp.br

Key Words: enamel, adhesive system, microshear bond strength, primary tooth.
This study evaluated the tensile and flexural strength of tungsten inert gas (TIG) welds in specimens made of commercially pure titanium (CP Ti) compared with laser welds. Sixty cylindrical specimens ( $2 \mathrm{~mm}$ diameter $\times 55 \mathrm{~mm}$ thick) were randomly assigned to 3 groups for each test $(n=10)$ : no welding (control), TIG welding (10 V, 36 A, 8 s) and $\mathrm{Nd}$ :YAG laser welding ( $380 \mathrm{~V}, 8 \mathrm{~ms}$ ). The specimens were radiographed and subjected to tensile and flexural strength tests at a crosshead speed of $1.0 \mathrm{~mm} / \mathrm{min}$ using a load cell of $500 \mathrm{kgf}$ applied on the welded interface or at the middle point of the non-welded specimens. Tensile strength data were analyzed by ANOVA and Tukey's test, and flexural strength data by the Kruskal-Wallis test $(\alpha=0.05)$. Non-welded specimens presented significantly higher tensile strength (control $=605.84 \pm 19.83)(p=0.015)$ and flexural strength (control=1908.75) $(\mathrm{p}=0.000)$ than TIG- and laser-welded ones. There were no significant differences $(p>0.05)$ between the welding types for neither the tensile strength test $(\mathrm{TIG}=514.90 \pm 37.76$; laser $=515.85 \pm 62.07)$ nor the flexural strength test $(\mathrm{TIG}=1559.66$; laser=1621.64). As far as tensile and flexural strengths are concerned, TIG was similar to laser and could be suitable to replace laser welding in implant-supported rehabilitations.

\section{Introduction}

The development of safe surgical techniques and biomaterials increased greatly the use of osseointegrated implants. However, research is still needed to make this method increasingly safer (1).

Titanium and its alloys are used since 1950, first in the aerospace industry and currently in several areas including Dentistry, due to its excellent biocompatibility, low density, high module of elasticity, high resistance to corrosion, low cost and low thermal conductibility (2-4). These characteristics allow their use by lost wax technique and mechanical and electronic polishing process is facilitated, increasing its applicability.

In Dentistry, commercially pure titanium (CP Ti) stands out with success as implant material even as prosthesis supra-structure, due to biocompatibility and low cost. In this way, $\mathrm{CP} \mathrm{Ti}$ is considered the ideal material for restorations that involve osseointegrated implants and metallic suprastructure restorations $(5,6)$. However, the strong chemical reactivity of $\mathrm{Ti}$ and its fast level of reaction and diffusion at high temperatures result in problems with welding, melting and brazing processes (7). The welding has the greatest potential of affecting material properties, usually increasing hardness and decreasing tensile strength and ductility $(8,9)$. Thus, the processes that seem to be suitable to weld titanium are plasma, electron beam, laser, hearth brazing, infrared brazing, metal inert gas (MIG) and tungsten inert gas $(\mathrm{TIG})(3,10)$. It is important to note that all these methods are performed in a protective atmosphere $(11,12)$, because the contamination with gases turns the metal crumbly and it can result in alterations of the crystalline structure, that influence directly on the mechanical properties of the titanium and its alloys. The laser process is the most common method used to weld titanium. It is characterized by a monochrome electromagnetic light whose energy beam can be concentrated in a focal point resulting in the union process (11). Some advantages of this method are the absence of direct contact with the welded area, more defined welding area with less heating and no influence of magnetic field on the laser beam $(13,14)$. However, the main disadvantage of laser welding is the cost of the equipment, which makes the implant-supported prostheses with titanium supra-structures expensive. Furthermore, researchers concluded that laser welding is effective, but the results may vary greatly because of the different intensities of radiation and argon gas flow used $(7,15)$.

In TIG welding, the arc is formed involving the nonconsumable electrode and the piece of metal. The electric or welding arc is formed by a flow of inert gas around the electrode minimizing oxidation during the welding process (16). This process is widely used in manufacturing and industrial maintenance, welding plates of small thickness (0.2 to $8 \mathrm{~mm}$ ), carbon steel, stainless steel, aluminum and 
its alloys, copper and its alloys, titanium, zirconium, nickel and its alloys and tungsten. As the cost of TIG welding equipment is lower than that of laser welding, this method could contribute significantly to reduce the final cost of oral rehabilitations.

Evaluating the effect of TIG welding on titanium properties (e.g.: tensile and flexural strength) as a less expensive alternative to laser welding is important to reduce the cost of implant-supported prostheses. This study evaluated the tensile and flexural strength of $\mathrm{TIG}$ and laser welds in CP Ti specimens. The work hypothesis was that the tensile and flexural strengths of $\mathrm{Cp} \mathrm{Ti}$ are not different for the TIG-welded and laser-welded groups.

\section{Material and Methods}

Sixty cylindrical titanium specimens $(2 \mathrm{~mm}$ diameter and $55 \mathrm{~mm}$ thick) were fabricated for the tensile and flexural strength tests using the lost-wax casting technique. Six wax rod patterns were distributed in each siliconcasting ring. Inclusion was done using Rematitam Plus investment (Dentaurum, Pforzheim, Germany) according to the manufacturer's instructions. The investment molds were placed in a furnace (Edgcon 5P; EDG, São Carlos, São Paulo, Brazil) to burnout wax patterns and expand the investment thermally. The heating and cooling rate was 5 ${ }^{\circ} \mathrm{C} / \mathrm{min}$, and the cycle steps were: room temperature up to $150{ }^{\circ} \mathrm{C}$, hold $90 \mathrm{~min} ; 150{ }^{\circ} \mathrm{C}$ to $250{ }^{\circ} \mathrm{C}$, hold $90 \mathrm{~min} ; 250$ ${ }^{\circ} \mathrm{C}$ to $1,000{ }^{\circ} \mathrm{C}$, hold $60 \mathrm{~min}$ and $1,000{ }^{\circ} \mathrm{C}$ to $400{ }^{\circ} \mathrm{C}$ with a holding time of no longer than 90 min before casting. The duration time of the complete cycle was $10 \mathrm{~h}$. After removal from the furnace, the investment molds were positioned in the casting machine (Rematitan; Dentaurum) where titanium was melted with a voltaic arc. Air was automatically evacuated from the casting machine's functional chamber and an inert argon atmosphere was provided for melting and casting. The molten titanium was injected into the investment mold by a combination of vacuum and pressure. To cast each investment mold, $22 \mathrm{~g}$ of CP Ti (Tritan, Titanium 99.6\%, Grade I; Dentaurum) were used. After the investment mold cooling, the castings were divested manually and airborne-particle abraded (Model Microjet III; EDG) with $50 \mu \mathrm{m}$ aluminum oxide (Aluminum Oxide 50; Asfer Indústria Química Ltda., São Caetano do Sul, $\mathrm{SP}$, Brazil), under 2 bar pressure for $5 \mathrm{~s}$, to remove residual investment. Castings were then separated from the sprue and randomly assigned to 3 groups $(n=10)$ for each test (tensile and flexural strength): no welding (control), TIG welding and $\mathrm{Nd}: \mathrm{YAG}$ laser welding.

A digital caliper (Mitutoyo Digimatic Caliper, model 500-151; Mitutoyo Corp., Tokyo, Japan) was used to delimit the central areas of the specimen that were sectioned with an extra high-quality carborundum disk (Dentorium Export
Ltd, New York, NY, USA).

The specimens were radiographed with periapical films (Ektaspeed Plus, Eastman Kodak, Rochester, NY, USA) to check the presence of porosities in an $\mathrm{x}$-ray unit with 60 $\mathrm{KV}, 10 \mathrm{~mA}, 0.6 \mathrm{~s}$ exposure time and a $10 \mathrm{~cm}$ focus-film distance. The radiographs are used to evaluate cast titanium and titanium alloy frameworks as an efficient method to identify internal porosities (15-17). Two specimens with excessive voids were excluded.

Specimens were positioned in the device by the lateral stems for the TIG and laser welds to be performed. For the TIG welding, the device/specimen set was placed on a working surface and welding was done with an electric Esab machine (Esab S/A, Contagem, MG, Brazil) with 10 V, $36 \mathrm{~A}$ and $8 \mathrm{~s}$ of argon post flow. For the laser welding, the set was placed inside the laser machine (Desktop Laser; Dentaurum) and welded with $380 \mathrm{~V}$ and pulse length of $8 \mathrm{~ms}$. After welding, the specimens were tested in a mechanical testing machine (Model DL 2000; EMIC, São José dos Pinhais, PR, Brazil) and subjected to shear bond testing with a $500-\mathrm{kgf}$ load cell at a crosshead speed of $1.0 \mathrm{~mm} / \mathrm{min}$. The tensile test value (MPa) was recorded as the maximum value before the disruption. A three point bending flexural test ( $\mathrm{MPa}$ ) was used for analysis of flexural strength.

Tensile strength data were analyzed by ANOVA and Tukey's test, and flexural strength data by the nonparametric Kruskal-Wallis test. All statistical analyses were performed with $\alpha$ equal to 0.05 .

\section{Results}

Non-welded specimens presented significantly higher tensile strength (control $=605.84 \pm 19.83)(p=0.015)$ an flexural strength (control $=1908.75)(p=0.000)$ than $\mathrm{TIG}$ - an laser-welded ones. There were no significant difference ( $p>0.05$ ) between the welding types for neither the tensil strength test $(\mathrm{TIG}=514.90 \pm 37.76$; laser $=515.85 \pm 62.07)$ no the flexural strength test $(\mathrm{TIG}=1559.66$; laser $=1621.64$ (Figs 1 and 2).

\section{Discussion}

Since its introduction in the 1980's, titanium and its alloys have been a material of great interest in Dentistry, mainly for dental implants, fixed and removable prostheses, due to its reduced cost, physical properties, biocompatibility, high corrosion resistance, low specific gravity and satisfactory mechanical properties $(1,3,4,8,9)$. However, many technical problems are associated with the use of Ti ср and its alloys in dental prostheses, as the welding process. In the welding process, three zones are formed on the metal surface: welded, heat-affected zone and metalbase zones. The quality of the joint is an important factor in determining the resistance of welded titanium $(3,18-20)$. 
The results obtained in this study demonstrated statistical differences between the experimental groups ( $\mathrm{TIG}$ and laser) and control. The TIG- and laser-welded specimens presented lower tensile strength values than the non-welded group, but there was no statistical difference between welding groups. Wiskott et al. (21) obtained similar results when $\mathrm{TIG}$ and laser methods were compared in relation to tensile results. The authors also studied the hardness, which was not indicated to evaluate the joints resistance, and just compared the welding types between them, but not to the control (no welding).

Due to the lower amount of gas included during

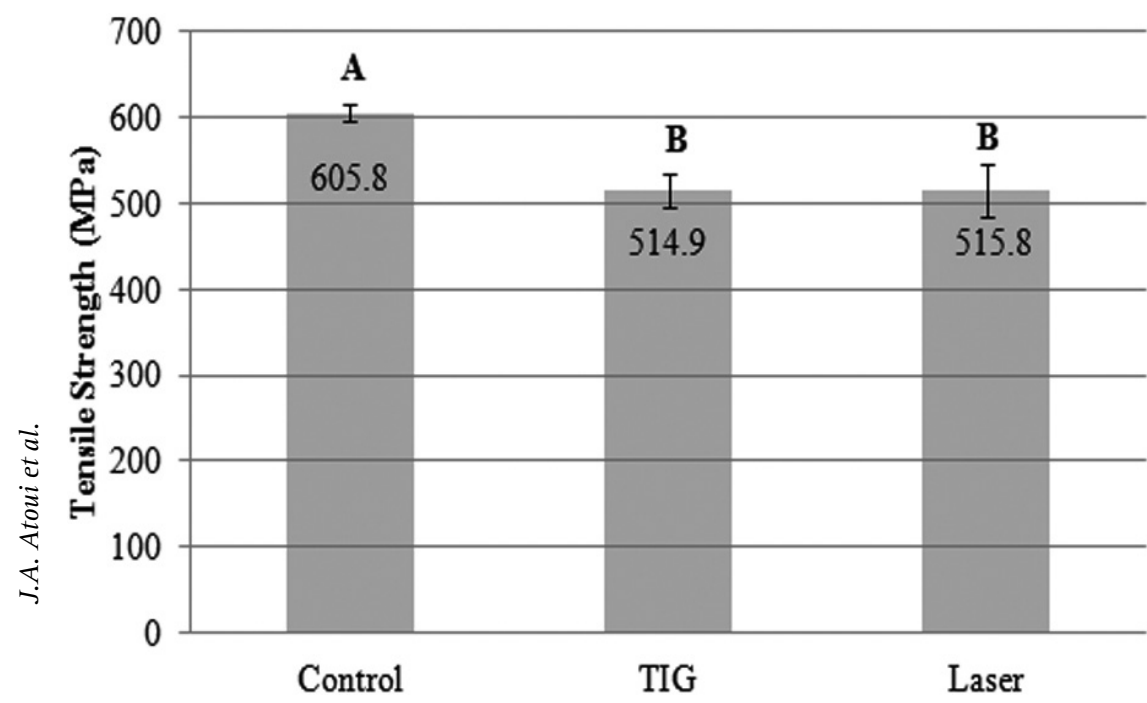

Figure 1. Tensile strength results. Error bars represent standard deviations $(\alpha=0.05)$. Different uppercase letters indicate statistically significant difference (Tukey's test).

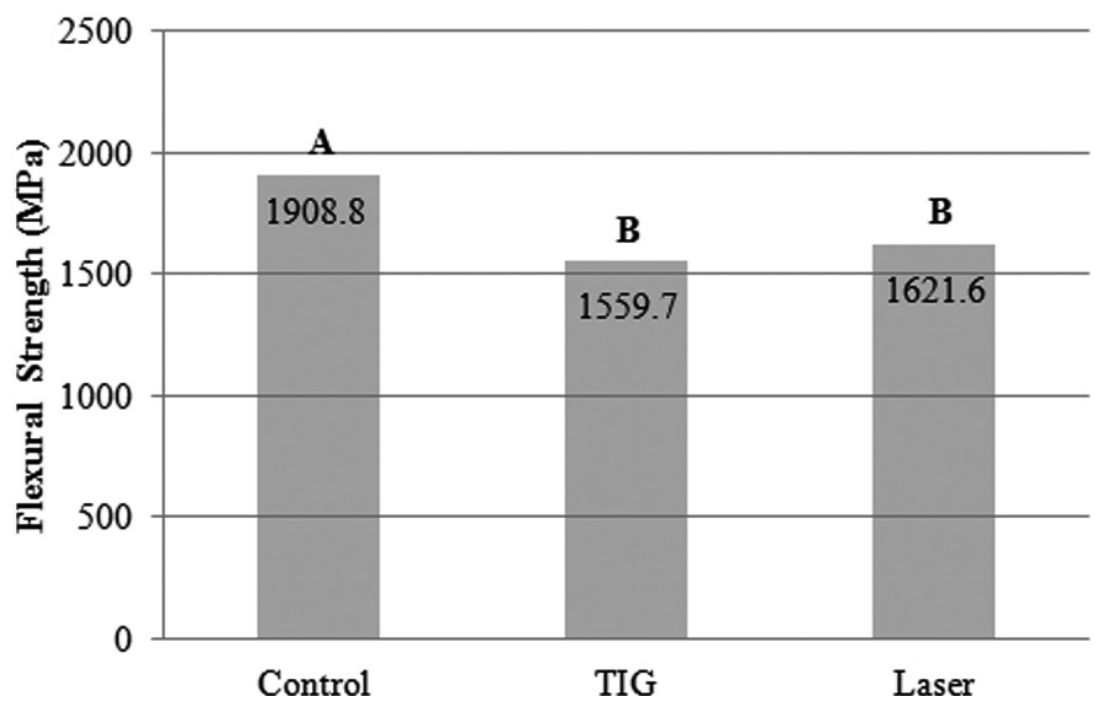

Figure 2. Flexural strength results. Different uppercase letters indicate statistically significant difference (Kruskal-Wallis test). titanium casting compared with the amount included during the welding process, hardness is increased and ductility is reduced (19). Some studies have reported that welded structures present worse properties than cast specimens, such as lower mechanical resistance, higher corrosion and increased pore incorporation $(11,22)$.

Using scanning electron microscopy, it was observed that the laser-welding region is not completely melted and the $0.7 \mathrm{~mm}$ penetration depth reduced specimen's resistance, indicating that this method is not suitable for welding surfaces exceeding $1 \mathrm{~mm}$ in diameter (22).

The welded laser mechanical strength depends on the type of welding metal $(23,24)$ quantity and laser wavelength, energy density, duration of exposure and pulse repetition rate (4). Titanium has low thermal conductivity, high melting point and it is extremely reactive at high temperatures (2). Titanium's low conductivity and high laser absorption capacity allow increasing the penetration depth into different thicknesses, without affecting its strength properties $(14,22)$. In this study, 2-mm diameter specimens were welded using at least four laser pulse applications (380 $\mathrm{V}$ and $8 \mathrm{~ms}$ ) on both sides to obtain complete welding and more substantiated results. Specimens with $2 \mathrm{~mm}$ in diameter were used because they are compatible with welded joints used in prosthodontics clinically.

There are some laser welding parameters that must be followed in order to obtain high-quality welding results $(3,15,24)$. Welding the specimen bilaterally significantly improves the welding strength (25). Studies suggested that the use of multi-pulsed laser on titanium can improve the depth of penetration and reduce damage to the surface $(11,23)$. No differences were found in the depth of penetration, according to pulse duration (23). When $3 \mathrm{~mm}$ diameter rods were evaluated, it was observed that the central portion was not well welded, which demonstrates low ductility, probably due to failure grains cleavage (12). 
The combination of laser welding and titanium was indicated as an efficient method $(12,21,24)$ despite the results differing with the applied radiation intensity $(3,9,20,24)$. Some studies suggested that the mechanical strength of laser-welded areas was similar or better than the non-welded metal $(3,9,19,22)$. The use of $300 \mathrm{~V}$ voltage and pulse duration of $12 \mathrm{~ms}$ may increase the welding depth and improve the mechanical properties of the welded joints $(3,9,19,22)$. In this study, despite the higher voltage $(380 \mathrm{~V})$ and lower exposure time $(8 \mathrm{~ms})$, the results were corresponding to these other studies findings, due to the proportionality of the adjustment parameters.

In the present study, visual analysis revealed that the heat-affected zone (HAZ) of TIG welding was greater than of the laser, despite the similar strength results. Exposure time and voltage were adjusted in order to compensate this method's limitation. Other factors should be considered in order to evaluate the HAZ by technicians and dentists, as the design of the joint, the energy released to the areas to be joined, the method of energy dispersion, the cooling rate and amount of contamination during the procedure.

The flexural strength test simulates the three-point of a prosthesis at least two elements. The results revealed no significant differences between the two welding methods, but there was significant difference between non-welded and welded specimens. Similar results were shown in the tensile strength test. Changes of the micro-crystalline structure and contamination of welded joints are suggested to be responsible for reducing considerably the flexural strength compared to the non-welded specimens (control).

The study of Rocha et al. (14) demonstrated differences between laser and TIG welding, where TIG welding is carried out under the following parameters: $10 \mathrm{~V}, 15-20 \mathrm{~A}$ and 12 $s$ post-flow time and it showed higher flexural strength than laser welding and without filling material. In this study, the argon was used to avoid the oxidation process that could be harmful to the process of union. There was no signifciant difference between the two welded groups for tensile and flexural strength. The same finding was observed in the study of Hart and Wilson (13), where the laser welding showed worse results than TIG welding. TIG welding is characterized by greater amount of heat, suggesting that more metal should be melted, resulting in more extensive, deeper and stronger gathering. In order to compensate the low energy during TIG welding, the equipment must be adjusted to apply a continued electrical discharge for a longer period (3 to $12 \mathrm{~s})(7,20)$.

Under the tested conditions and considering the study limitations, it may be concluded that, as far as tensile strength and flexural strength are concerned, the TIG method used to weld titanium was similar to laser and could be suitable to replace laser welding, reducing the final cost of implant-supported rehabilitations.

\section{Resumo}

Este estudo avaliou a resistência à tração e à flexão de soldas feitas com gás inerte de tungstênio (TIG) em amostras de titânio comercialmente puro (Ti CP) em comparação com a solda a laser. Sessenta amostras cilindricas (diâmetro de $2 \mathrm{~mm}$ e espessura de $55 \mathrm{~mm}$ ) foram distribuídas aleatoriamente em três grupos para cada ensaio $(n=10)$ : sem solda (controle), solda TIG (10V, 36A, 8 s) e solda com laser de Nd:YAG (380 V, 8 $\mathrm{ms})$. As amostras foram radiografadas e submetidas aos testes de resistência à tração e à flexão em máquina de ensaios mecânicos à velocidade de $1 \mathrm{~mm} / \mathrm{min}$ com célula de carga de $500 \mathrm{kgf}$ aplicada na interface soldada ou no ponto médio das amostras controle. Os dados de resistência à tração foram analisados estatisticamente por ANOVA e teste de Tukey e os dados de resistência à flexão pelo teste de Kruskal-Wallis $(\alpha=0,05)$. Espécimes não-soldados apresentaram resistência à tração (controle $=605,84 \pm 19,83$ ) $(p=0,015)$ e resistência à flexão (controle $=1908,75) \quad(p=0,000)$ significantemente maiores que os solados com TIG ou laser. Não houve diferença estatisticamente significante $(p>0.05)$ entre os tipos de solda no teste de resistência à tração $(T I G=514,90 \pm 37,76$; laser $=515,85 \pm 62,07)$ nem no teste de resistência à flexão ( $\mathrm{TIG}=1559,66$; laser=1621,64). As resistências à tração e à flexão foram similares quando as amostras foram soldadas com TIG e a laser.

\section{References}

1. Yamazoe J, Nakagawa M, Matono Y, Takeuchi A, Ishikawa K. The development of $\mathrm{Ti}$ alloys for dental implant with high corrosion resistance and mechanical strength. Dent Mat J 2007;26:260-267.

2. Contreras $E F$, Henriques $G E$, Giolo SR, Nobilo MA. Fit of cast commercially pure titanium and Ti-6Al-4V alloy crowns before and after marginal refinement by electrical discharge machining. J Prosthet Dent 2002;88:467-472.

3. Liu J, Watanabe I, Yoshida K, Atsuta M. Joint strength of laser-welded titanium. Dent Mat 2002;18:143-148.

4. Fujioka S, Kakimoto K, Inoue T, Okazaki J, Komasa Y. Metallurgical effects on titanium by laser welding on dental stone. Dent Mat J 2003;22:581591.

5. Jemt T, Bergendal B, Arvidsson K, Bergendal T, Karlsson U, Linden BO, et al.. Laser-welded titanium frameworks supported by implants in the edentulous maxilla: a 2-year prospective multicenter study. Int J Prosthodont 1998;11:551-557.

6. Ortorp A, Jemt T. Clinical experiences of implant-supported prostheses with laser-welded titanium frameworks in the partially edentulous jaw: a 5-year follow-up study. Clin Implant Dent Relat Res 1999;1:84-91.

7. Orsi IA, Raimundo LB, Bezzon OL, Nobilo MA, Kuri SE, Rovere CA, et al.. Evaluation of anodic behavior of commercially pure titanium in tungsten inert gas and laser welds. J Prosthodont 2011;20:28-31.

8. Monday JJ, Asgar K. Tensile strength comparison of presoldered and postsoldered joints. J Prosthet Dent 1986;55:23-27.

9. Sjögren $G$, Andersson M, Bergman M. Laser welding of titanium in dentistry. Acta Odontol Scand 1988;46:247-253.

10. Lyra e Silva JP, Fernandes Neto AJ, Raposo LHA, Novais VR, Araujo CA, Cavalcante $L A L$, et al.. Effect of plasma welding parameters on the flexural strength of Ti-6Al-4V alloy. Braz Dent J 2012;23:686-691.

11. Poulon-Quintin A., Watanabe I, Watanabe E, Bertrand C. Microstructure and mechanical properties of surface treated cast titanium with $\mathrm{Nd}: Y A G$ laser. Dent Mater 2012;28:945-951.

12. Wang RR, Welsch GE. Joining titanium materials with tungsten inert gas welding, laser welding, and infrared brazing. J Prosthet Dent 1995;74:521-530.

13. Hart CN, Wilson PR. Evaluation of welded titanium joints used with cantilevered implant-supported prostheses. J Prosthet Dent 2006;96:2532.

14. Rocha $\mathrm{R}$, Pinheiro $\mathrm{AL}$, Villaverde $\mathrm{AB}$. Flexural strength of pure $\mathrm{Ti}, \mathrm{Ni}-\mathrm{Cr}$ and Co-Cr alloys submitted to Nd:YAG laser or TIG welding. Braz Dent J 2006;17:20-23. 
15. Takayama $Y$, Nomoto R.; Nakajima $\mathrm{H}$, Ohkubo C. Effects of argon gas flow rate on laser-welding. Dent Mat J 2012;31:316-326.

16. Jemt $T$, Linden B. Fixed implant-supported prosthesis with welded titanium frameworks. Int J Periodontics Restorative Dent 1992;12:177184.

17. Nuñez JMC, Takahashi JMFK, Henriques GEP, Nóbilo MAA, Consani RLX, Mesquita MF. Radiographic inspection of porosity in Ti-6AI-4V laser welded joints. Braz Oral Res 2011;25:103-108.

18. Nuñes-Pantoja JM, Vaz LG, Nobilo MA, Henriques GE, Mesquita MF. Effects of laser-weld joint opening size on fatigue strength of Ti-6Al-4V structures with several diameters. J Oral Rehabil 2011;38:196-201.

19. Berg E, Wagnere WC, Davik G, Dootz ER. Mechanical properties of laserwelded cast and wrought titanium. J Prosthet Dent 1995;74:250-257.

20. Chai T, Chou CK. Mechanical properties of laser-welded cast titanium joints under different conditions. J Prosthet Dent 1998;79:477-483

21. Wiskott HW, Doumas MT, Scherrer SS, Susz C, Belser UC. Microstructures of brazings and welds using grade 2 commercially pure titanium. Int J
Prosthodont. 2001:14:40-47.

22. Roggensack M, Walter MH, Böning KW. Studies on laser- and plasmawelded titanium. Dent Mat 1993;9:104-107.

23. Watanabe I, Baba N. Effect of welding parameters on penetration of $\mathrm{Nd}$ :YAG laser into cast Ti and $\mathrm{Au}$ - and Ag-based alloys. Quintessence Int 2007;38:614-619.

24. Watanabe I, Topham DS. Tensile strength and elongation of laser-welded Ti and Ti-6AL-7NB. J Biomed Mater Res B Appl Biomater 2004;71:46-51.

25. Zavanelli RA, Guilherme AS, Henriques GEP, Nóbilo MAA, Mesquita MF. Corrosion-fatigue of laser-repaired commercially pure titanium and Ti-6Al-4V alloy under different test environments. J Oral Rehabil 2004;31:1029-1034. 